\title{
In Memoriam Prof. J. van der Hoeve
}

On April 26th, 1952, Professor J. van der Hoeve died at Leyden. In him the Netherlands lost one of their greatest men. He was unequalled as an ambassador for Dutch Science.

An end has been put to a most industrious life. Van der Hoeve was born in 1878; he was a student of medicine at Leyden University, where he took his medical degree at the age of 22. He specialised in ophthalmology at the Clinic of Prof. Roster at Leyden and took his doctor's degree in 1902.

Van der Hoeve was a man of great erudition, of keen observation and with a strong capacity for coordination. An example of his erudition is his thesis,

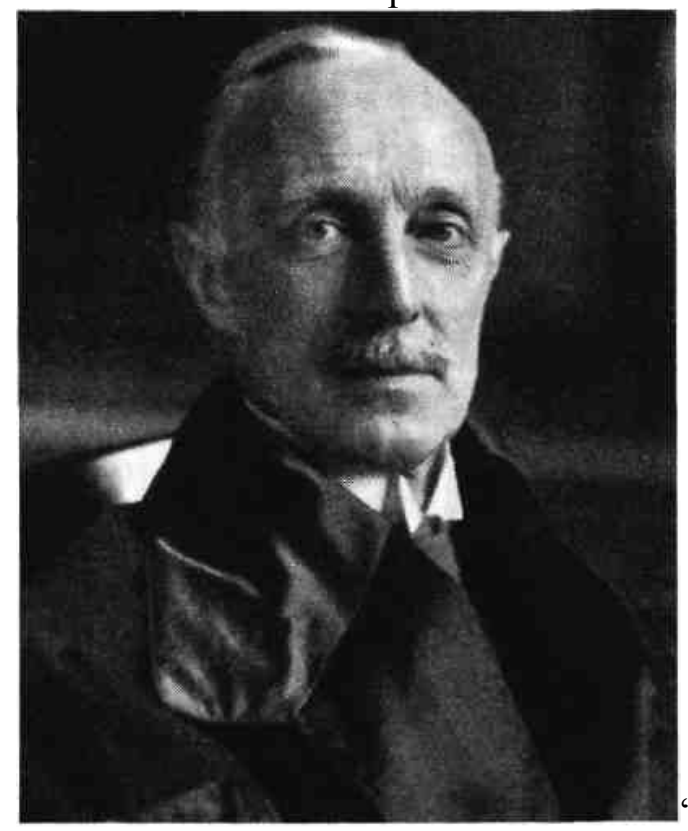

Necrologia

191

brilliant work did not pass unnoticed and in 1922 he was asked to treat the same subject in Graefe-Saemisch's textbook. His keen power of observation is illustrated by his discovery of the enlarged blind spot as an early symptom of retrobulbar neuritis in ethmoï-ditis; while his powter of coordination gave him the vision to realize that the diseases of Bourneville, of

Recklinghausen, of von Hippel-Lindau and of Sturge-Weber form one group which he named phacomatosis.

Seeing the wide-spread connections between problems was one of Van der Hoeve's most characteristic qualities, as can be seen from the titles of his official addresses. When he was appointed Professor at Groningen in 1913, his inaugural address was on: "Ophthalmology in Connection with the Other Branches of Medical Science". Appointed Professor at Leyden in 1919, he held an inaugural address on: "The Present State of Ophthalmology". His presidential 
address at the Dutch Physical and Medical Congress in 1935 on: "Cooperation and Limits", and his Rectorial Address in 1937 on "The Prevention of Blindness", also show his wide vision. These qualities, together with a warm heart, made him the ideal mediator for clearing away difficulties by personal action. Never was an appeal made to him in vain. His integrity was always above suspicion. He always thought well of others so long as the contrary had not been proved, and thus he aroused the best qualities in other people.

He was one of the leaders of the resistance of the University against the Germans.

Abroad too his friends were many, and as Duke-Elder says in the 5th volume of his textbook, which opens with a portrait of Van der Hoeve: "His contributions to the advance of many aspects of ophthalmology have been great and he will long be remembered for the dominating part he played for more than a quarter of a century in cementing international relationship among his colleagues of all countries of the world."

Many honours were bestowed on him: 1923 he was chosen as a member of the Dutch Royal Academy of Science; 1932 he became president thereof. He was honorary doctor of Edinburgh and Heidelberg Universities. He was presented with the Mackenzie Medal in 1930 and the Bowman-medal and the Doyne-medal in 1932. In 1929 he was the brilliant President of the International Ophthalmo-logical Congress at Amsterdam.

192

Necrologia

Van der Hoeue was a master in surgery, possessing a clever hand guided by a clever mind. For his patients he was a fatherly friend, full of compassion, even to simulators, the exposure of whom was a real sport to him.

He was a man of a radiant good humour; and it might seem that life was without difficulties for him, but actually the contrary was true. A great character does not develop without self-conquest. And thus one can but have the greatest admiration for the way in which he mastered the difficulties of his personal life.

The impression he made upon me, as one of his many pupils, I am unable to describe; only one word reaches the heart of it:gratitude, gratitude above all! Colenbrander.

Buchbesprechungen - Book Reviews - Livres Nouveaux

G. E. Jayle et A. Dubois-Poulsen: L'année thérapeutique en ophtalmologie.

Tome II. Expansion scientifique française, Paris 1951. 397 Seiten; ffr. 2000.-.

Der vorliegende zweite Band dieses Periodicums, über dessen ersten Band bereits in dieser Zeitschrift berichtet worden ist, zeigt die gleiehen Vorzüge wie das frühere Werk. Es ist auch hier wieder mit großem Geschick und voller Sachkenntnis seitens der einzelnen Mitarbeiter, die alle zu nennen den Rahmen einer kurzen Anzeige sprengen würde, die inhaltliche und formale Höhe der Darstellung eingehalten worden. Neben einzelnen operativen Fragen findet auch in diesera Band wieder die Wirkung der Vitamin-Therapie in weiterem Sinne Berücksichtigung. Mehrere Arbeiten befassen sich mit den Gefäßerkrankungen des inneren Auges, speziell der Retina (Bietti, Bonamour, Deodati). Die Ka-pitel Streptomycin (Miller) und Chemotherapie der Augentuberkulose (Vialle-font) betreffen aktuelle Fragen. Die Beziehungen der Augenheilkunde zu den Zahnerkrankungen erörtert Jean-Sédan; Francois bespricht die Behandlung der chronischen Uveitis. Auch die nicht speziell erwähnten Kapitel sind von Interesse.

Die Ophthalmologie kann für diese Bereicherung der Literatur dankbar sein.

Diesem zweiten Bande ist der Index für den ersten Band angeknüpft, was vielleicht eine gewisse Erschwerung bei der Benutzung des Werkes zu Nach-schlagezwecken bedeutet. 
F. Für den nächsten Band ist ein großes Übersichtsreferat über die Wirkungdes Cortisons und von A.C.T.H. bei der Behandlung der Uveitis in Aussichtgestellt. A. Bruckner. 